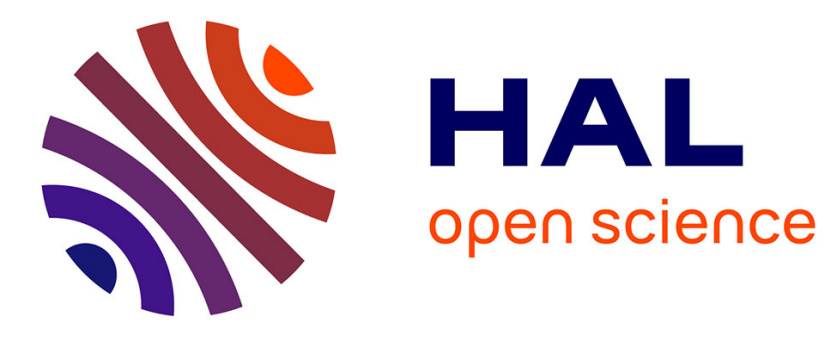

\title{
Firm technological innovation persistence: Organizational innovation matters
}

Naciba Haned, Christian Le Bas, Caroline Mothe, Uyen Nguyen

\section{To cite this version:}

Naciba Haned, Christian Le Bas, Caroline Mothe, Uyen Nguyen. Firm technological innovation persistence: Organizational innovation matters. 2012. halshs-00703289

\section{HAL Id: halshs-00703289 \\ https://shs.hal.science/halshs-00703289}

Preprint submitted on 1 Jun 2012

HAL is a multi-disciplinary open access archive for the deposit and dissemination of scientific research documents, whether they are published or not. The documents may come from teaching and research institutions in France or abroad, or from public or private research centers.
L'archive ouverte pluridisciplinaire HAL, est destinée au dépôt et à la diffusion de documents scientifiques de niveau recherche, publiés ou non, émanant des établissements d'enseignement et de recherche français ou étrangers, des laboratoires publics ou privés. 
Firm technological innovation persistence:

Organizational innovation matters

Naciba Haned, Christian Le Bas, Caroline Mothe, Uyen Nguyen 


\section{GATE Groupe d'Analyse et de Théorie Économique Lyon-St Étienne}

93, chemin des Mouilles 69130 Ecully - France

Tel. +33(0)4 72866060

Fax $+33(0) 472866090$

6, rue Basse des Rives 42023 Saint-Etienne cedex 02 - France

Tel. +33 (0)4 77421960

Fax. +33 (0)4 77421950

Messagerie électronique / Email : gate@gate.cnrs.fr

Téléchargement / Download : http://www.gate.cnrs.fr - Publications / Working Papers 


\section{Firm technological innovation persistence: Organizational innovation matters.}

Naciba Haned, Université de Lyon, Lyon, F-69007, France ; CNRS, GATE Lyon SaintEtienne, Ecully, F-69130, France. ESDES-UCLy, 23, Place Carnot, 69002 Lyon.

nhaned@univ-catholyon.fr

Christian Le Bas, Université de Lyon, Lyon, F-69007, France ; CNRS, GATE Lyon SaintEtienne, Ecully, F-69130, France, Université Lyon 2, Lyon, F-69007, France.

christian.lebas@univ-lyon2.fr

Caroline Mothe, Université de Savoie, IAE Savoie Mont-Blanc, IREGE, France.4, chemin de Bellevue, BP 80439, 74944 Annecy le Vieux, France.

Caroline.Mothe@,univ-savoie.fr

Uyen Nguyen, CEPS/Instead, Luxembourg. 44, Rue Emile Mark.L-4620 Differdange, Luxembourg.

ThiThucUyen.Nguyen@ceps.lu 


\begin{abstract}
.
Organizational innovation favors technological innovation, but does it also influence technological innovation persistence? This article investigates empirically the pattern of technological innovation persistence and tests the potential impact of organizational innovation using firm-level data from three waves of the French Community Innovation Surveys. Evidence shows a positive effect of organizational innovation on technological innovation persistence, according to various measures of organizational innovation. Moreover, this impact is more significant for complex innovators (i.e., those who innovate in both products and processes). These results highlight the complexity of managing organizational practices with regard to the firm's technological innovation. They also add to comprehension of the drivers of innovation persistence, through a focus on an often forgotten dimension of innovation in a broader sense.
\end{abstract}

\title{
Résumé
}

Les innovations organisationnelles favorisent les innovations technologiques mais influencent-elles la persistance à l'innovation technologique ? Cet article analyse empiriquement un modèle de persistance de l'innovation et teste sur des données de panel l'impact potentiel des innovations d'organisation. La base de données est issue de trois vagues d'enquêtes communautaires sur l'innovation réalisées sur un échantillon d'entreprises françaises. Les résultats montrent un impact positif de plusieurs mesures des innovations organisationnelles sur la capacité des firmes à innover de façon persistante. Toutefois, l'impact est plus significatif pour les innovateurs complexes (innovant dans les produits et les procédés). Les résultats mettent en lumière la complexité des pratiques de management organisationnel. Ils aident aussi à comprendre plus finement les déterminants de la persistance à l'innovation à travers une analyse centrée sur une dimension souvent oubliée : l'innovation organisationnelle.

\section{Keywords: Organizational Innovation, Technological Innovation, Persistence}

JEL codes: L 21, 0 32, 033 
Economic analyses of innovation persistence mainly focus on technological changes or drivers of technological innovation persistence. Yet firms' innovation capabilities do not depend solely on their internal technological competencies (e.g., R\&D activities); rather, their ability to develop a broad set of complementary activities and organizational strategies appears crucial for increasing the performance of their innovation processes. The importance of managing various resource types, including non-technological ones, is highlighted by the resource-based view of the firm and evolutionary economic theory (e.g., Penrose 1959; Nelson and Winter 1982; Wernerfelt 1984; Teece 1988). Firms that combine customer, technological, and organizational skills bring more innovations to the market (e.g., Lokshin et al. 2008a).

Research is only beginning to shed light on "very complex and under-investigated topic" (Evangelista and Vezzani, 2010: 1262) of the relationships between technological and nontechnological innovations. However, broadening the scope of analysis beyond the technological domain is crucial to understand firms' economic performance, because complex organizational innovation modes serve to explain this performance. Battisti and Stoneman (2010) find that the range of innovations reflects two multi-innovation factors, 'organizational' and 'technological', which are complementary. In a meta-analysis of organizational determinants on product and process innovations Damanpour and Aravind (2006) summarize the impact of organizational innovation practices on technological innovation. Tatikonda and Montoya-Weiss (2001) build on the resource-based view of firms to characterize relationships among organizational process factors, product development capabilities, and performance in product development projects. Specifically, organizational process factors appear associated with the achievement of operational outcome targets for new product performance and thus customer satisfaction. Armbruster et al. (2008) also argue that organizational innovations serve as prerequisites and facilitators of the efficient use of technical product and process innovations, whose success depends on the degree to which the organizational structures and processes adapt to the new technologies. Organizational innovations offer an immediate source of competitive advantage, because they have significant impacts on business performance in terms of productivity, lead times, quality, and flexibility. Armbruster et al. (2008) thus recommend further clarification of distinct types of innovation, and especially organizational innovations.

In response to such calls for insight into the influence of organizational innovation strategies on technological innovation outcomes, we highlight the effect of non-technological innovation on firms' technological innovation persistence. Unlike previous studies of 
innovation persistence, we consider the specific role of organizational innovation, which clearly is important for corporate performance but has not been researched with regard to its potential impact on technological innovation persistence. To fill this gap, we begin by establishing our focal research question, based on a survey of extant literature. We then describe our data set before outlining our methodology and empirical models. Next, we discuss our results and conclude with some avenues for further research.

\section{Organizational innovation and technological innovation persistence}

\subsection{The neglected role of organizational innovation}

Innovation refers to the adoption of an idea, behavior, system, policy, program, device, process, product, or service that is new to the organization (Damanpour 1992). Although Damanpour (1992) considers the general concept of organizational innovation as related to all parts of the organization, most approaches divide innovation into technological and organizational versions. Phillips (1997) separates technological and non-technological innovation to include new marketing strategies and changes to management techniques or organizational structures in the latter category. Most literature in innovation management and economics instead concentrates on technological innovation, without clear guidelines for how firms should address the types of innovation that may lead to technological innovation (e.g., 'administrative innovation', Damanpour 1991). The expanded definition of innovation in the Oslo Manual (OECD 2005) treats organizational innovation as an innovation type, separate from the technological innovation type. Yet the question remains: How does organizational innovation affect technological innovation and thus global firm performance?

Pavitt (2005) argues that technological innovation consists of three overlapping processes: the production of scientific and technological knowledge, the translation of this knowledge into working artifacts (products, systems, processes, services), and response to market needs. Generally, technological innovation encompasses product and process innovation. Product innovation is the introduction of goods or services that are new or significantly improved with respect to their specifications or intended uses, such as significant improvements in technical specifications, components and materials, incorporated software, user friendliness, or other functional characteristics (OECD 2005). Process innovation is defined as the implementation of a new or significantly improved production or delivery method, including significant changes in techniques, equipment, and/or software. Process innovations might attempt to 
decrease unit costs of production or delivery, increase quality, or produce or deliver new or significantly improved products (OECD 2005).

Lam (2005) also proposes two meanings for organizational innovation: the creation or adoption of an idea new to the organization (organizational innovation lato sensu) and changes in managerial practices or kinds of organizational forms (organizational innovation stricto sensu). Theoretically, organizational innovation is a broad concept that encompasses strategies, structural, and behavioral dimensions, yet there is no consensus about its definition. Some authors include all types of innovation under its umbrella (e.g., Daft 1978; Kimberly and Evanisko 1981; Damanpour and Evan 1984; Crossan and Apaydin 2010), whereas others, including this study, use it in contrast with technological innovation (e.g., Gumusluoğlu and Ilsev 2009) by drawing on the distinction between technological and non-technological innovation (e.g., Baldridge and Burnham 1975; Battisti and Stoneman 2010). In the absence of a unified theoretical definition, we follow the OECD (2005), which views an organizational innovation as 'the implementation of a new organizational method in the firm's business practices, knowledge management, workplace organization or external relations that has not been previously used by the firm'.

Studies of the relationships between organizational and technological innovations often highlight that technological innovation drives organizational changes within the firm (Henderson and Clark 1990; Dougherty 1992), because firms introducing technological innovation must reorganize their production, workforce, sales, and distribution systems. Another research stream suggests an inverse relationship, such that organizational innovation enhances flexibility and creativity, which facilitates the development of technological innovations (Greenan et al. 1993; Lokshin et al. 2008b). Organizational (re)structuring, if it leads to structural renewal, could facilitate other types of innovations (Günday et al. 2011). For example, Staropoli (1998) emphasizes how external relations and networks can enhance technological innovation in pharmaceutical firms, and Bharadwaj and Menon (2000) show that innovation is a function of individual efforts and organizational systems aimed at facilitating creativity, such that successful product innovation depends partly on organizational factors. Studying interrelations of different innovation strategies, Schmidt and Rammer (2007) indicate that a combination of technological and non-technological innovation has a positive impact on innovation performance. Similarly, Günday et al. (2011) find a positive relationship between organizational innovation and technological innovation. With sample of fast-moving consumer goods firms in Germany, Lokshin et al. (2008a) study the effect of organizational skills on firms' innovative performance. Firms implementing a 
combination of customer, organizational, and technological skills tend to introduce more innovations. Mothe and Nguyen (2012) find that the effects of non-technological innovations differ depending on the phase of the innovation process. Organizational innovations significantly increase the likelihood of innovation, but not its commercial success.

These studies all acknowledge the crucial role of organizational practices on competitive advantage and firm innovation, in the sense that they provide input into the firm's innovation process and innovation capability. Therefore, we argue that firms that dedicate more resources to new organizational forms should be in a better position to use new skills and technologies efficiently.

\subsection{Three frameworks for technological innovation persistence}

Few studies deal with organizational innovation in relation to technological innovation in the context of persistence, though Antonelli, Crespi, and Scellato (2012) find a relatively higher persistence level for product innovation than for process innovation. When a firm undertakes different types of innovation jointly (e.g., product, process, and organizational), it achieves a lower degree of state dependence, acknowledging for the fact that, for firms combining several innovations (product, process and organization), the state of the period depends less on the state of the previous period. To put it simply, 'general' innovators are less persistent. Le Bas and Poussing (2012), using two waves of the Community Innovation Surveys (CIS) in Luxembourg, indicate that complex innovators (product and process) are more inclined to be persistent than single innovators (product or process). Organizational innovation exerts a positive impact only on the probability of being a complex innovator.

In turn, we consider the role of organizational innovation for technological innovation persistence, according to three complementary explanations of technological innovation persistence at the firm level (Le Bas and Poussing, 2012). First, the knowledge accumulation hypothesis stipulates that experience in innovation is associated with dynamic increasing returns, in the form of learning-by-doing and learning-to-learn effects, which enhance knowledge stocks and the probability of future innovations (Geroski, van Reenen, and Walters 1997; Duguet and Monjon 2002; Latham and Le Bas 2006). Learning in this sense pertains to a capacity to innovate later. According to the OECD (2005) definition, we might anticipate that new practices for organizing work drive the changing processes, and new methods of organizing external relations increase the level of technological knowledge exchanged (learning by interacting) and spur the emergence of improved technologies. Schmidt and Rammer (2007) provide some support for this approach. Taking into account the 
interrelations across different innovation strategies, they note that the combination of technological and non-technological innovation has a positive impact on effective innovation performance.

Second, the 'success breeds success' approach indicates that a firm gains locked-in advantages over other firms through successful innovations. Specifically, innovation feeds profitability, which funds subsequent innovation activities. Economic and commercial successes matter in this regard, and Polder et al. (2010) argue that organizational innovation also plays a role. Product and process innovations, in combination with organizational innovation, have positive impacts on firm productivity. Cordelier (2009) provides similar results, obtained from the market shares of French firms after they innovate; product or process innovations are more profitable than organizational innovations in the industrial sector, but when firms combine different types of innovations, their market shares grow more. Ultimately, the greater the combination of innovation types, the higher the market share growth. Thus a complex innovator implementing organizational innovations should perform better than a complex innovator that does not adopt new organizational practices. Evangelista and Vezzani (2010) support this view by showing that firms that introduce both technological and organizational innovations have a clear competitive advantage over both non-innovating firms and those introducing technological innovations only. All these studies imply that organizational innovations, used together with technological innovations, exert a positive effect on firm economic performance.

Third, noting sunk costs in R\&D activities, Antonelli et al. (2012) interpret evidence of persistence in innovation efforts as intertemporal stability in R\&D efforts. The firm chooses between investing or not in R\&D activities, but sunk costs encourage the continuity of R\&D expenditures. That is, a firm deciding for the first time to engage in R\&D activities incurs start-up costs that are not recoverable, and the resulting sunk costs represent a barrier, to both entry into and exit from R\&D activity. At first glance, organizational innovation seems irrelevant in this context, but if firms implement new practices to organize the work or procedures of their R\&D department or adopt new methods to interact with external relations, the cost of their R\&D might decrease over time (from a resource allocation perspective), which would increase incentives to persist in their R\&D activity.

Following this line of research, we highlight the effects of organizational innovation strategies on firms' technological innovation persistence. Unlike Antonelli et al. (2012), we focus on the impact of organizational innovation on technological innovation persistence. Thus, we can compare our findings, derived from three waves of France's CIS, with those 
recently published by Le Bas and Poussing (2012), using two waves of the Luxembourg CIS. Our research thus features a larger and more representative sample, while also providing more detail about the underlying dynamic mechanisms by which organizational innovation affects technological innovation persistence, using panel econometrics (versus simple cross-sectional estimates) and more complex variables for organizational innovation that can account for continuity and intensity effects.

\section{Data, variables, and descriptive statistics}

\subsection{Data collection}

Community Innovation Surveys (CIS) follow a subject approach to studying innovation, with the firm as the statistical unit (rather than an individual innovation), and combine census and stratified sampling methods for each wave. The stratum variables are consistently activity and size, and the data collection includes both innovators and non-innovators. For statistical consistency, we draw on three successive waves of the French CIS: CIS4 (2002-2004, which we call $\mathrm{t}_{0}$ ), CIS6 (2004-2006, or $\mathrm{t}_{1}$ ), and CIS8 (2006-2008, or $\mathrm{t}_{2}$ ), as provided by the French Institute of Statistics (INSEE) and collected by the Industrial Studies and Statistics Office (SESSI).

These most recent surveys are homogenous in their definitions of innovation. We thus can identify the same questions that relate to product, process, and organizational innovations, though they differed in the waves prior to the 2005 CIS. For the analysis, we merged the three survey waves, such that the final data set includes only firms that responded to all three waves and excluded any that entered or exited the market midway through 2002-2008. The balanced panel consisted of 1,180 manufacturing firms with 20 or more employees.

The sector composition and size distribution of the final sample does not vary substantially from one period to another. Therefore, we describe the balanced data set for 2006, an intermediate year during our study period (see Table I). More than half the sample consists of low or medium-low technology firms (according to $\mathrm{NACE}^{1}$ classifications), operating in sectors such as plastic products, metals (12\%), food, textiles, and wood (20\%). The rest of the sample features high and medium-high technology firms ( $40 \%$ of the total), operating in

\footnotetext{
${ }^{1} \mathrm{NACE}$ is the 'statistical classification of economic activities in the European Community', used uniformly by all member states. We classified manufacturing industries according to their global technological intensity with NACE Revision 1.1 for the periods $t_{0}$ and $t_{1}$, whereas $t_{2}$ was covered by the NACE Revision 2, according to the Eurostat classification (http://epp.eurostat.ec.europa.eu/cache/ITY_SDDS/Annexes/hrst_st_esms_an9.pdf).
} 
industries such as electronics, instruments, and chemicals. Regarding the size distribution, we find a majority (66\%) of medium-sized firms (250-1000 employees) in our sample.

\section{INSERT TABLE I ABOUT HERE}

\subsection{Variables and descriptive statistics}

\section{i. Dependent variables}

We used four dependent variables. The CIS considers a firm innovative if, in a given period of time (i.e., three years prior to the survey), it introduced a new product or process. We designed dichotomous variables to measure whether the firm produced an innovation during that period, as well as to assess the type of innovation (product, process, or organization). Product innovators introduced, in the three years prior to the survey, goods or services that were 'either new or significantly improved with respect to its fundamental characteristics, technical specifications, incorporated software or other immaterial components, intended uses, or user friendliness' (OECD 2005). Process innovators implemented "new techniques ... or significantly improved production technology, new and significantly improved methods of supplying services and of delivering products' (OECD 2005).

From these definitions, to study the persistent innovation behavior of firms, we identified four types of innovators: pure product, pure process, single, and complex. The binary variable (Only_prod) takes a value of 1 if the firm is a pure product innovator; (Only_proc) takes the value of 1 if the firm is a pure process innovator; the (Single) variable equals 1 if the firm is a single innovator, such that it introduced either a product or a process innovation during the studied period; and the fourth dependent variable (Complex) takes a value of 1 if the firm is a complex innovator because it introduced both product and process innovations. For each type of innovator, we considered the dependent variable related to each of the three time periods (see Tables II and III for definitions and descriptive statistics).

\section{INSERT TABLES II and III ABOUT HERE}

\section{ii. Organizational innovation}

Our main hypothesis relates to the impact of organizational innovation on firms' technological persistence. Several measures of organizational innovation appear in previous studies examining technological innovation (Schmidt and Rammer 2007; Armbruster et al. 
2008; Mothe and Nguyen 2010, 2012). Generally, organizational innovations include changes in business practices (including knowledge management), in the workplace organization or the firm's external relations. Prior research has tended to concentrate on the probability of introducing new organizational practices during a reference period, a procedure that fails to account for the degree of intensity of the organizational innovation or the temporal continuity of organizational change. Thus, these approaches cannot assess some key aspects of organizational innovation, such as intensity, continuity, or the impact on the dynamics of firms' innovation behavior.

Instead, we adopted new measures of organizational innovation that could (1) handle the temporal continuity of organizational innovation (ConOrg) and (2) examine the degree of intensity of organizational innovation (IntOrg). Specifically, we introduced two variables in each case to control for the continuity of implementing organizational innovation across two periods of time, such that we attain four organizational innovation variables.

To construct ConOrg, we began with data about organizational innovations implemented during the reference period for each wave and created the binary composite variable of organizational innovation (Org). The CIS04 reported three organizational practices: (1) new or significantly changed corporate strategy, (2) advanced management techniques, and (3) major changes to organizational structure. The CIS06 included data on four organizational practices: (1) new business practices for organizing work and procedures, (2) new knowledge management systems, (3) new methods of workplace organization, and (4) new methods of organizing external relations. We constructed four dummy variables for each practice. Finally, CIS08 provides information about three organizational practices: (1) new business practices for organizing work and procedures, (2) new methods of workplace organization, and (3) new methods of organizing external relations. ${ }^{2}$ The variable $\operatorname{Org}(\mathbf{t})(\mathrm{t}-2, \mathrm{t}-1)$ equals 1 if at least one organizational practice was implemented during $\mathrm{t}(\mathrm{t}-2, \mathrm{t}-1)$ and 0 otherwise.

In a second step, we constructed ConOrg using Org. The variable ConOrg $(\mathbf{t}-\mathbf{1}, \mathbf{t})$, for example, depends on the firms' organizational innovation during $t-1$ (2004-2006) and $t$ (2006-2008). It equals 0 if firms did not introduce organizational innovation in any of the two periods, 1 if organizational innovation appears only in $\mathrm{t}-1(\operatorname{Org}(\mathbf{t}-\mathbf{1})=1$ and $\operatorname{Org}(\mathbf{t})=0), 2$ if it has been introduced only in $\mathrm{t}(\operatorname{Org}(\mathbf{t}-\mathbf{1})=0$ and $\operatorname{Org}(\mathbf{t})=1)$, and 3 if it is continuously adopted throughout both periods $(\operatorname{Org}(\mathbf{t}-\mathbf{1})=1$ and $\operatorname{Org}(\mathbf{t})=1)$ (see Table III).

\footnotetext{
${ }^{2}$ A methodological change between the CIS06 and CIS08 reintegrated 'knowledge management' back into 'new business practices for organizing procedures' for CIS08.
} 
The second variable of organizational continuity, $\operatorname{ConOrg}(\mathbf{t}-\mathbf{2}, \mathbf{t}-\mathbf{1})$, follows similar principles: It equals 0 if no organizational innovation was adopted in $t-2$ (2002-2004) or $t$ 1 (2004-2006), 1 if it were adopted only in $t-2,2$ if it adopted only in $t-1$, and 3 if it has been continuously adopted. Both indicators of organizational innovation thus are intertemporal, such that we may control for the temporal dimension of the impact of organizational innovation on the dynamics of technological innovation. Although the items pertaining to diverse organizational practices are not the same across different CIS waves, this issue does not appear to be a problem for our analysis, because we determine ConOrg on the basis of the composite organizational variable determined for each reference period.

In Table IV we provide the descriptive statistics pertaining to the relationship between organizational innovation and technological innovators' profiles. More than $10 \%$ of pure product innovators do not introduce any organizational innovation in either $\mathrm{t}-2$ or $\mathrm{t}-1$, $11.63 \%$ introduce organizational innovations in $\mathrm{t}-2$ but not $\mathrm{t}-1,21.52 \%$ implement organizational innovations only in $\mathrm{t}-1$, and $56.42 \%$ do so in both periods.

\section{INSERT TABLE IV ABOUT HERE}

In addition, we introduced two other variables to control for the degree of intensity of organizational innovation over time. Specifically, IntOrg(t) is determined on the basis of data about the three organizational practices reported in CIS08. It equals 0 if none of the organizational practices arise in $t^{3}, 1$ if only one practice is adopted; 2 if two practices have been adopted, and 3 if all three practices are adopted during $t$.

Similarly, the construction of IntOrg(t - 1) uses information about four organizational practices reported in CIS06: (1) new business practices for organizing procedures, (2) new methods for organizing work responsibilities and decision making, (3) new methods for organizing external relations with other firms or public institutions, and (4) knowledge management procedures. Thus IntOrg(t $-\mathbf{1})$ equals 0 if firms never introduce organizational practices in $\mathrm{t}-1,1$ if they adopt one practice, 2 if they introduce two practices, 3 if three practices have been adopted, and 4 if all practices are adopted. ${ }^{4}$

\footnotetext{
${ }^{3}$ In this case, the firm does not introduce any organizational innovations.

${ }^{4}$ We interpret $\operatorname{IntOrg}($.$) as a measure of the intensity of organizational innovation. It should depict the diversity$ of new practices implemented by the firm.
} 


\section{iii. Other explanatory variables}

We added several explanatory variables, in addition to organizational innovation, to our model. Prior literature suggests that the probability of innovation depends on firm characteristics and sector-specific features. For example, external and internal R\&D investments per employee raise the stock of technological knowledge in firms, because R\&D increases the firm's ability to capture external knowledge (Cohen and Levinthal 1990) and exerts a positive impact on the propensity to innovate (Raymond et al. 2010). We included two variables to differentiate external from internal R\&D. First, Int_RD(t-1) represents internal $R \& D$ intensity, measured as in-house $R \& D$ expenditures divided by the number of employees for the lagged period $\mathrm{t}-1$. Second, Ext_RD(t-1) accounts for external R\&D intensity, measured as external $R \& D$ expenditures divided by the number of employees for the lagged period $t-1 .^{5}$ Because non-innovators do not provide R\&D expenses in CIS, we assume they have no R\&D expenses (i.e., these variables equal 0 for non-innovators).

Regarding firms' characteristics, we introduced four variables. First, we account for firm size, which is an important determinant of innovation activities (Cohen 1995), using a dichotomous ordered variable with four size classes: 1 for the firms with fewer than 50 employees, 2 for those with 50-250 employees, 3 for 250-1000 employees, and 4 for those with more than 1000 employees. Second, we account for market conditions, which provides a proxy for the geographic area of sales for each firm (Peters 2008). This qualitative ordered variable ranges from 1 to 4 , according to the situation of the geographic market where the firm sells its goods and products: 1 if the market is local or regional, 2 if it is national, 3 for EU member countries, and 4 for all other countries. Most firms in our sample fall into the fourth category $(70 \%)$ and about $15 \%$ sell their goods and services throughout the European Union. Third, we address ownership status, because firms that are part of a group may have more incentive for innovation activities through their easier access to financing (Love and Roper 2001). It is also important to control for the estimations at the group level, because some firms in our sample must apply the innovation strategy adopted by their headquarters (Mairesse and Mohnen 2010). We use Gp to represent ownership, a binary variable that equals 1 if the firm is part of a group. Most firms (approximately 80\%) in our sample belong to a group. Fourth, sector controls usually involve adding dummies for each industry, but

\footnotetext{
${ }^{5}$ The total amount of in-house R\&D is given directly in CIS. The total amount of external R\&D is a variable that we constructed from an average of three inputs: (1) the amount dedicated to the purchase of external R\&D; (2) the acquisition of machinery, equipment, and software dedicated to R\&D; and (3) the acquisition of external knowledge.
} 
instead, to address the technological level of the industry, we control for industrial specificity with a dichotomous ordered variable (Dumsect), ranging from 1 to 4: high-tech, mediumhigh-tech, medium-low-tech, and low-tech sectors (or NACE, Rev 1 at the three-digit level of aggregation).

\section{Estimation method}

Our goal is to test for the probability of being an innovator in period $t_{2}$, as a function of the intensity of past innovation behavior in the two previous periods. We thus needed to estimate not only past innovation behavior but also the different types of innovations that firms have adopted and the extent to which they are more persistent with organizational innovations. However, in panel data sets, investigating the impact of observed and unobserved individual characteristics and their relation with initial conditions can be problematic (Heckman 1981). Empirical literature on persistent innovation resolves this issue by using dynamic panel models. Previous studies of the persistence of innovation generally use binary discrete choice modeling, out of consideration of the nature of the data sets and variables. Peters (2008) investigates the persistence effects of innovation activities using several binary dependent variables that express the innovation behavior of firms as a function of past innovation and other explanatory variables, indicating variation across individuals and time. She then uses a second set of explanatory variables that are time constant and implements a probit model with the Wooldridge estimation method to control for unobserved heterogeneity. Raymond et al. (2010) use a panel of CIS-derived Dutch manufacturing firms to study the persistence of innovation with a maximum likelihood dynamic tobit model that accounts for individual effects and initial conditions. Antonelli et al. (2012) use a dynamic probit random effect model to evaluate the persistence of innovation among a set of Italian manufacturing firms.

We retained a dynamic probit random model. With our panel, we can differentiate the sources of persistence from past innovation behavior versus those due to individual heterogeneity. In our basic model, we explain current innovation status (measured with alternative innovation variables), $\mathrm{y}_{\mathrm{it}}^{*}$, by previous innovation experience $\left(\mathrm{y}_{\mathrm{i}, \mathrm{t}-\mathrm{1}}\right)$ and other explanatory variables that attempt to measure observable and unobservable firm-specific attributes. Thus our dynamic probit model is as follows:

$$
\begin{aligned}
& \mathrm{y}_{\mathrm{i}, \mathrm{t}}^{*}=\gamma \mathrm{y}_{\mathrm{i}, \mathrm{t}-1}+\beta \mathrm{x}_{\mathrm{i}, \mathrm{t}}+\mathrm{u}_{\mathrm{i}}+\varepsilon_{\mathrm{i}, \mathrm{t}} \quad \mathrm{i}=1, \ldots, \mathrm{N} \text { and } \mathrm{t}=2, \ldots, \mathrm{T} \text {, and (1) } \\
& \mathrm{P}\left(\mathrm{y}_{\mathrm{i}, \mathrm{t}}=1 / \mathrm{x}_{\mathrm{i}, \mathrm{t}}, \mathrm{u}_{\mathrm{i}}\right)=\Phi\left(\gamma \gamma_{\mathrm{i}, \mathrm{t}-1}+\beta \mathrm{x}_{\mathrm{i}, \mathrm{t}}+\mathrm{u}_{\mathrm{i}}\right),
\end{aligned}
$$


where $\mathrm{x}_{\mathrm{i}, \mathrm{t}}$ is a $\mathrm{k}$-dimensional row vector that includes variables that vary across individuals and time, balanced by a $\gamma$-state dependence parameter; $u_{i}$ captures unobservable firm-specific attributes that are assumed to be constant over time and correlated by definition with $\mathrm{y}_{\mathrm{i}, \mathrm{t}-\mathrm{i}}$; and $\varepsilon_{\mathrm{i}, \mathrm{t}}$ includes other time-varying, unobservable determinants.

There are two issues to resolve for proper estimations of these models. The first relates to a case of unobserved heterogeneity, which clearly occurs when $u_{i}>0$. The second problem is linked to initial conditions, which, if not properly accounted for, could lead to an overestimation of the dependent variable, such as when $y_{\text {io }}$ is correlated with the unobserved random effect. To handle this problem, we write $u_{i}$ as a function of $y_{i o}$ and $\alpha_{i}$, as Wooldridge (2005) suggests, such that

$$
\mathrm{u}_{\mathrm{i}}=\psi+\varepsilon_{0} \mathrm{y}_{\mathrm{i}, 0}+\mathrm{x}_{\mathrm{i}} \varepsilon+\mathrm{a}_{\mathrm{i}} \text {; where } \mathrm{a}_{\mathrm{i}} \sim \mathrm{N}\left(0, \sigma^{2}{ }_{\mathrm{a}}\right) \text { and is independent of } \mathrm{y}_{\mathrm{io}} \text { and } \mathrm{z}_{\mathrm{i}} .
$$

This joint distribution enables us to apply a conditional maximum likelihood estimator,

$$
\mathrm{u}_{\mathrm{i}}=\alpha_{0}+\alpha_{1} \mathrm{y}_{\mathrm{i}, 0}+\overline{\mathrm{x}}_{\mathrm{i}} \alpha_{2}+\mathrm{a}_{\mathrm{i}}(2),
$$

where $\bar{x}_{i}$ are the time averages of $x_{i t}$ that control for unobserved heterogeneity (Peters 2008). Therefore, our estimated model, transforming Equation (1) and taking Equation (2) into account, becomes:

$$
\mathrm{P}\left(\mathrm{y}_{\mathrm{i}, \mathrm{t}}=1 / \mathrm{yio}, \mathrm{yi} 1, \mathrm{yi} 2, \mathrm{xi}, \overline{\mathrm{x}}_{\mathrm{i}}, \mathrm{a}_{\mathrm{i}}\right)=\Phi\left(\gamma \gamma_{\mathrm{i}, \mathrm{t}-1}+\mathrm{x}_{\mathrm{i}, \mathrm{t}} \beta+\alpha_{0}+\alpha_{1} \mathrm{y}_{\mathrm{i}, 0}+\overline{\mathrm{x}}_{\mathrm{i}} \alpha_{2}+\mathrm{a}_{\mathrm{i}}\right) .(3)
$$

\section{Estimation results}

\subsection{Econometric results}

We estimate dynamic probit random models, using the approach recommended by Wooldridge (2005), to account for unobserved heterogeneity and overcome initial condition problems (Peters 2008). With this procedure, we can examine the factors that explain the dynamics of different profiles of technological innovators, taking into account different dynamic specifications of organizational innovation.

First, to gain a better understanding of the role of organizational innovation, we estimated a set of models that each included one measure of organizational innovation and four profiles of technological innovators: pure product, pure process, single, and complex. Model 1 provides the standard model and includes the two measures of temporal continuity of organizational innovation, ConOrg(t $\mathbf{- 1}, \mathbf{t})$. In Table $V$ we present the results when $\operatorname{ConOrg}(\mathbf{t}-\mathbf{1}, \mathbf{t})$ is a 
dynamic specification of the organizational continuity between the lagged period $(\mathrm{t}-1)$ and the current one $(\mathrm{t})$.

\section{INSERT TABLE V ABOUT HERE}

Thus we determine that the persistence parameters for single and complex technological innovators are positive and significant, but we find no evidence of persistence for simple product or process innovators. ${ }^{6}$ Being a single or a complex innovator in the previous time period positively correlates with the probability of being a single or complex innovator in the future. The value of the estimated coefficient also indicates the strength of the persistence dynamic, that is, the degree of influence of past innovation on a current decision to innovate. A higher coefficient indicates a stronger persistence process. The results show that complex innovators are prone to be more persistent than single innovators, and the initial conditions have positive and highly significant effects, such that firms' initial innovation status is strongly correlated with unobserved heterogeneity.

As another important result, we determine that the degree of organizational continuity is significant and positively correlated with the probability of being a single or complex innovator. Firms that occasionally implement organizational innovation during the lagged or current period and those that have continuously implemented it in both periods exhibit a higher probability of being complex innovators, compared with firms that implemented no organizational practices during the two periods. This expected result, in line with Le Bas and Poussing's (2012) findings, confirms the crucial role of organizational innovation for generating complex innovation over time. Its effect is twice as strong for complex innovators as for single innovators, but it does not explain firms' likelihood to be pure product or process innovators.

The geographical market variable is positively and significantly correlated with the pure product and single innovators. Firms open to the international market, facing higher foreign competition, exhibit a higher probability to innovate over time compared with firms that sell products or services only in local or regional markets. We also find a positive effect of past $R \& D$ intensity variables on current pure product and single innovators. Firms that invest in internal $\mathrm{R} \& \mathrm{D}$ and the acquisition of external knowledge likely innovate in product or in

\footnotetext{
${ }^{6}$ In a first step, we also estimated simple models, assuming the absence of individual effects and exogenous initial conditions. The persistence parameters were positive and highly significant for all innovator profiles. However, in these unrealistic conditions, overestimation of the dependent variable is likely, so the significance of the persistence parameters does not mean that true persistence exists. These results are available on request.
} 
product or process, which reflects the role of $R \& D$ in both types of innovations, in line with the sunk costs hypothesis. That is, R\&D activities drive technological innovation, so the dynamics of the former induce those of the latter. Yet internal and external R\&D intensity variables do not reveal any impact on current complex innovation persistence. At first sight, this result appears counterintuitive; perhaps the relatively small number of complex innovators in our sample (approximately 8\%) created some estimation problems. Also surprisingly, we do not find any evidence of an impact of firm size on any technological innovation profile. In our model, being larger cannot explain persistent innovation. ${ }^{7}$

\subsection{Sensitivity analysis and robustness checks}

To check the robustness of the results, we ran further regressions with different specifications of our main explanatory variable: organizational innovation. We therefore introduce three new measures of organizational innovation: $\operatorname{ConOrg}(\mathbf{t}-2, \mathbf{t}-\mathbf{1}), \operatorname{IntOrg}(\mathbf{t})$, and IntOrg(t-1), with the results reported, respectively, in Tables VI, VII, and VIII. The estimated coefficients and their level of significance are roughly the same as those reported in Model 1. The effects of other explanatory variables, such as R\&D intensity and size, are similar across the various models, such that our estimations are robust for the control variables. Therefore, we report only the estimated coefficients related to the block of the main independent variables.

In Model 2 in Table VI, in which ConOrg(t-2, $\mathbf{t}-\mathbf{1})$ is specified as a dynamic measure of the organizational continuity between the periods $t-2$ and $t-1$, the results for the persistence parameters are similar to those in Model 1. Pure product and pure process innovators do not appear persistent. On the contrary, the persistence parameters of single and complex innovators are positive and highly significant. These results confirm our previous findings from Model 1: Firms with the capacity to introduce products and/or processes in the past have a higher chance of being persistent than those that have implemented only products or only processes. The effects of organizational innovation on single and complex innovators' behaviors are positive and significant, though not as strong as in Model 1. This finding seems to suggest that organizational innovation, once it has been continuously adopted over two recent periods of time $(t-1$ and $t)$, is more efficient for generating a higher probability of innovating than that adopted for two preceding periods $(t-2, t-1)$ that are more distant in

\footnotetext{
${ }^{7}$ In addition, the individual average of firm size (Sizemean) is positive and significant for pure product innovators and negative and significant for pure process innovators, which indicates substantial correlations between these variables and unobserved individual heterogeneity.
} 
time from the reference period $t$. That is, there is a temporal dimension to the efficiency of the effect of organizational innovation on technological innovation.

In addition to Models 1 and 2, we estimated several other models that include our new indicators of temporal intensity of organizational innovation, $\operatorname{IntOrg}(\mathbf{t})$ and $\operatorname{IntOrg}(\mathbf{t}-\mathbf{1})$. We therefore explore another aspect of firms' intensity, in terms of organizational innovation practices. Recall that IntOrg(t) is a proxy for the degree of organizational intensity in period t (CIS8, 2006-2008), and it takes a value from 0 to 3, depending on the type of combinations of organizational practices reported in CIS8. Thus, we can determine whether, aside from firms' characteristics and R\&D activities, the intensity of organizational practices affects the persistence parameters. Models 3-5 thus mirror Models 1 and 2, except in the indicators of organizational innovation.

\section{INSERT TABLE VI ABOUT HERE}

Turning to organizational innovation, the estimation results for IntOrg(t) (Model 3) in Table VII indicate that the pure product innovation variable is significant when we control for the degree of organizational intensity in the current period, all else being equal. The fact that firms implement more than two organizational practices in the current period could change the dynamics of their product innovation behavior, compared with a case in which no organizational practices are adopted.

\section{INSERT TABLE VII ABOUT HERE}

The interpretation of these results is twofold. First, the joint implementation of organizational practices during the current period might induce a complementary effect, in terms of management and competence profitability, that enhances firms' capacity to continue to introduce new or improved products over time. Second, product innovators in general seem to achieve higher growth rates (Colombelli, Haned, and Le Bas 2011), which enables them to devote more resources to innovation activities and which could, in turn, create a higher capacity to innovate persistently, though this effect holds only after we control for the degree of organizational intensity. As for the other innovator profiles, we observe that the persistence parameters are positive and significant for complex innovators and highly significant for single innovators. With regard to the impact of organizational innovation, the organizational parameters are positive and highly significant for pure product, single, and complex innovators. The simultaneous introduction of more than one organizational practice during the three-year period t enhances firms' technological innovation capacity in that period. 
Finally, we present the results for the last model with $\operatorname{IntOrg}(\mathbf{t}-\mathbf{1})$ in Table VIII.

\section{INSERT TABLE VIII ABOUT HERE}

With these organizational innovation variables, all else being equal, single technological innovation remains persistent. In contrast, the persistence parameters for pure product and complex innovators are no longer significant. At first sight, this result might seem contradictory, but conditional on the degree of organizational intensity in the current period (IntOrg(t)), the two innovators profiles are persistent. These results may reflect the effects of lagged time returns of organizational innovation on current innovations.

Overall, the results across three models confirm that the joint implementation of organizational practices, compared with a case in which no organizational practices are adopted, has a crucial impact in terms of leading firms to innovate and enhancing their technological innovation capacity in the same period. There also could be a temporal dimension, in terms of returns on organizational strategies undertaken during the previous periods on current firms' likelihood to innovate.

\section{Discussion and conclusion}

With this study, we have attempted to explore the consequences of organizational innovation on the patterns of firm technological innovation persistence. This research complements previous literature by providing detailed statistical evidence of the impact of organizational innovations, then inserting them as regressors in different empirical models. In so doing, we provide new insights into the relationship between nontechnological and technological innovation and add to comprehension of the impact of organizational innovation on technological innovation persistence. Three waves of French CIS data enabled us to examine the determinants of four profiles of technological innovators, focusing on different dynamic specifications of organizational innovation. These findings enrich the learning approach to innovation persistence. Product, process, and organization innovation exhibit strong, systematic interactions (Antonelli, Crespi, and Scellato 2012). Implementing new practices or procedures, new methods of work responsibilities, and new external relations all have consequences for (or offer incentives to) the design of newly structured products or improved processes in general.

Two key results thus emerge from our empirical analysis among French manufacturing firms. First, we find persistence in innovation but also that this trend does not hold for all types of innovators. Our methodology builds on the idea that different kinds of innovators 
exist. We explicitly distinguish pure product, pure process, single (product or process), and complex (product and process) innovators. In line with another recent study using the Luxembourg CIS, we find that complex innovators are more persistent (Le Bas and Poussing 2012), likely due to the positive returns on past investments and the role of accumulating competencies during the previous period, which then enhance firms' capacity to innovate persistently in the future. These results also reaffirm the existence of system effects and synergies among alternative innovations. Competencies and knowledge gained during product development processes spill over to projects designed to improve innovation processes. Conversely, innovation in processes enhances firm efficiency, which can improve capacities to introduce new goods or services (Le Bas and Poussing 2012). Thus, firms that have combined product and process innovations in the past are more likely to be prepared, in terms of innovations opportunities, competencies, and work procedures, to introduce complex innovations in the present and future.

Second, and perhaps even more important, our estimations reveal a positive impact of organizational innovations on technological innovation persistence. This impact is neither general nor always of the same magnitude. Organizational innovation exerts a positive impact on complex innovators but almost never on pure process innovators. We have tracked the effects of two aspects of organizational innovation: relative continuity in the implementation of organizational innovation and the level of intensity in organizational innovation behavior. If the organizational innovation goes farther back, its effect is weak. That is, a specific organizational innovation exerts an effect on technological innovation in the short term, leaving almost no positive propagation effects in subsequent time periods. Instead, intensity matters more significantly and positively. The more practices are implemented by the firm, the higher the probability it remains an innovator (though this pattern does not apply to pure process innovators).

We also acknowledge that our approach is clearly exploratory. The three CIS surveys do not use the same questions pertaining to organizational innovation, nor has there been any standard, unanimously accepted definition of organizational innovation in academic research. Therefore, we hope ongoing studies elaborate on the concept of organizational innovation and reach a standardized definition, similar to those that already exist for product and process innovations. In addition, technological and organizational innovations significantly help explain firm performance, but we lack proper models to track the effect of different types of innovation on firm performance over time. Thus, it is necessary to expand on our analysis of innovation, beyond technological aspects, to gain a better understanding of firms' economic 
performance. Further research should include qualitative, longitudinal studies that can effectively tackle the continuity and intensity aspects of organizational innovation.

Finally, our study provides several new insights regarding tools to support innovation policies. The extant targets of regional and national innovation policies have been product and process innovations; we show that organizational innovation matters, perhaps even more. New routines and organizational practices by the firm not only affect its current technological innovation but also exert lasting effects on its innovation activities. Thus organizational innovation should be a more important feature in the design of new types of public support. 


\section{Table I. Sectoral composition and size distribution, 2006}

\begin{tabular}{|c|c|c|c|}
\hline Branches & $\begin{array}{l}\text { NACE two-digit codes: } \\
\text { NACE Rev 1.1 }\end{array}$ & Number & Percentage \\
\hline Pharmaceuticals & $24.41-24.42$ & 47 & 3.98 \\
\hline $\begin{array}{l}\text { Computers, office machinery and } \\
\text { electronics-communication }\end{array}$ & 30 and 32 & 30 & 2.54 \\
\hline $\begin{array}{l}\text { Medical, precision, and optical } \\
\text { instruments, watches and clocks }\end{array}$ & 33 & 22 & 1.86 \\
\hline Aerospace & 35.3 & 27 & 2.29 \\
\hline Chemicals & 24 (excluding 24.41 and 24.42) & 92 & 7.80 \\
\hline Machinery and equipment & 29 & 106 & 8.98 \\
\hline Electrical machinery & 31 & 72 & 6.10 \\
\hline Motor vehicles and transport equipment & $\begin{array}{l}34-35 \text { (excluding } 35.1 \text { and } \\
35.3 \text { ) }\end{array}$ & 99 & 8.39 \\
\hline Petroleum refining & 23 & 10 & 0.85 \\
\hline $\begin{array}{l}\text { Rubber and plastic products and other } \\
\text { non-metallic mineral products }\end{array}$ & $25-26$ & 146 & 12.37 \\
\hline Metals & $27-28$ & 133 & 11.27 \\
\hline Shipbuilding & 35.1 & 4 & 0.34 \\
\hline Other manufacturing & $36.2-36.6$ & 29 & 2.46 \\
\hline Food & 15 & 194 & 16.44 \\
\hline Textiles & $17-19$ & 59 & 5.00 \\
\hline Wood, paper and furniture & $20-21$ and 36.1 & 88 & 7.46 \\
\hline $\begin{array}{l}\text { Printing and reproduction of recorded } \\
\text { media }\end{array}$ & 22 (excluding 22.3) & 22 & 1.86 \\
\hline Total & & 1180 & 100 \\
\hline \multicolumn{4}{|l|}{ Technological intensity } \\
\hline Low-technology & & 363 & 30.76 \\
\hline Medium low-technology & & 322 & 27.29 \\
\hline Medium high-technology & & 369 & 31.27 \\
\hline High-technology & & 126 & 10.68 \\
\hline Total & & 1180 & 100 \\
\hline \multicolumn{4}{|l|}{ Size class } \\
\hline Less than 50 & & 54 & 4.58 \\
\hline $50-250$ & & 154 & 13.05 \\
\hline $250-1000$ & & 786 & 66.61 \\
\hline More than 1000 & & 186 & 15.76 \\
\hline Totals & & 1180 & 100 \\
\hline
\end{tabular}




\section{Table II. Variables}

\begin{tabular}{|c|c|c|}
\hline Variables & Type & Description \\
\hline & & $\begin{array}{l}\text { Alternative endogenous variables of innovation performance indicators all } \\
\text { displayed for the year } 2008 \text { (present period, } \mathrm{t} \text { ) }\end{array}$ \\
\hline Only_prod & $\mathrm{B}$ & $\begin{array}{l}\text { Equals } 1 \text { for firms that are "pure product innovators": this category includes the } \\
\text { firms that introduce a new or significantly improved good or service with respect } \\
\text { to its capabilities, user friendliness, components or sub-systems }\end{array}$ \\
\hline Only_proc & $\mathrm{B}$ & $\begin{array}{l}\text { Equals } 1 \text { for firms that are "pure process innovators": this category includes firms } \\
\text { that at least one type of one of the three process innovations regarding any new or } \\
\text { significantly improved (1) methods of manufacturing or producing goods or } \\
\text { services (2) logistics, delivery or distribution methods for your inputs, goods or } \\
\text { services (3) supporting activities for your processes, such as maintenance, } \\
\text { systems or operations for purchasing, accounting, or computing }\end{array}$ \\
\hline Single & $\mathrm{B}$ & Equals 1 for firms that have introduced a product or a process innovation \\
\hline Complex & B & Equals 1 for firms that have introduced both product and process innovations \\
\hline
\end{tabular}

\section{Varying across individuals and time}

Organizational innovation (several variables) and R\&D expenses

\begin{tabular}{lll}
\hline \hline ConOrg(t-1,t) DO & $\begin{array}{l}\text { Equals } 0 \text { if firms did not introduced organizational innovation in either of the } \\
\text { two periods; } 1 \text { if organizational innovation is introduced only in } t-1 ; 2 \text { if it is } \\
\text { introduced only in } t ; 3 \text { if it is continuously adopted during } t-1 \text { and } t .\end{array}$
\end{tabular}

ConOrg(t-2,t-1) DO Equals 0 if no organizational innovation was adopted in $\mathrm{t}-2$ and $\mathrm{t}-1 ; 1$ if it is adopted only in $\mathrm{t}-2 ; 2$ if it is adopted only in $\mathrm{t}-1$; and 3 if it is continuously adopted during the two periods.

$\operatorname{IntOrg}(\mathrm{t}) \quad$ DO Equals 0 if none of the organizational practices are adopted in $\mathrm{t} ; 1$ if only one practice was adopted; 2 if two practices were adopted; and 3 if both three practices were adopted

$\operatorname{IntOrg}(\mathrm{t}-1) \quad$ DO $\quad$ Equals 0 if firms did not introduce any organizational practices in $\mathrm{t}-1 ; 1$ if only one practice was adopted; 2 if only two practices were adopted; 3 if 3 practices were adopted and 4 if all practices were adopted.

Int_RD $\mathrm{RD}_{\mathrm{t}-1} \quad \mathrm{Q} \quad$ Internal $\mathrm{R} \& \mathrm{D}$ expenses (estimated amount of expenditures for in-house $\mathrm{R} \& \mathrm{D}$ that includes capital expenditures on buildings and equipment specifically dedicated to R\&D) divided by the total number of employees for the year 2006 .

Ext_RD $\mathrm{t}_{-1} \quad \mathrm{Q} \quad$ External R\&D expenses (average of three CIS variables: (1) the amount dedicated to the purchase of external R\&D, (2) the acquisition of acquisition of machinery, equipment and software - that exclude expenditures on equipment for R\&D- and (3) the acquisition of external knowledge) divided by the number of employees for the year 2006.

Firm characteristics, year 2008 (present, period t)

\begin{tabular}{lll}
\hline \hline Size $_{\mathrm{t}}$ & DO & Ranging from 1 to $4: 1$ if the firm has less than 50 employees, 2 if the firm has \\
& \\
& \\
& 4 if it has more than 1000 employees.
\end{tabular}


Market $_{\mathrm{t}}$

$\mathrm{Gp}_{\mathrm{t}}$

B

Dumsect $_{t}$

$\mathrm{DO}$

Ranging from 1 to 4 according the situation of the geographic market where the enterprise sells its goods and products: 1 if the market is local or regional, 2 if it is national, 3 if it concerns EU member countries, 4 for all other countries.

Equals 1 if the firm is part of a group

Score ranging from 1 to 4 to reflect the technological intensity of sectors, based on NACE Rev 1.1 at three-digit level for compiling aggregates: 1 for high-technological activities that include pharmaceuticals, computers, office machinery, electronics and communication, medical, precision, and optical instruments, watches and clocks and aerospace; 2 for medium-high technological activities that include chemicals, machinery and equipment, electrical machinery, motor vehicles and transport equipment; 3 for mediumlow technological activities that include petroleum refining, rubber and plastic products and other non-metallic mineral products, metals, shipbuilding and other manufacturing activities; 4 for low-technological activities that include food, textiles, wood, paper and furniture and printing and reproduction of recorded media.

\section{Variables measuring individual heterogeneity (time averages of explanatory variables) Q MGp; MDumsect; MSize; MMarket}

Notes: B indicates binary, DO dichotomous ordered variable, and Q indicates quantitative variables. 
Table III. Summary statistics

\begin{tabular}{|c|c|c|c|c|c|}
\hline Variable & Obs. & Mean & Std. Dev. & Min & $\operatorname{Max}$ \\
\hline \multicolumn{6}{|c|}{ Dependent variables } \\
\hline Only_prod & 1180 & 0,63 & 0,483 & 0 & 1 \\
\hline Only_proc & 1180 & 0,10 & 0,302 & 0 & 1 \\
\hline Single & 1180 & 0,74 & 0,440 & 0 & 1 \\
\hline Complex & 1180 & 0,08 & 0,272 & 0 & 1 \\
\hline \multicolumn{6}{|c|}{ Organizational variables } \\
\hline ConOrg $(\mathrm{t}-1, \mathrm{t})$ & 1180 & 1.01 & 1.286 & 0 & 3 \\
\hline ConOrg $(\mathrm{t}-2, \mathrm{t}-1)$ & 1180 & .98 & 1.242 & 0 & 3 \\
\hline $\operatorname{IntOrg}(\mathrm{t})$ & 1180 & 1.11 & 1.139 & 0 & 3 \\
\hline IntOrg(t-1) & 1180 & 1.33 & 1.245 & 0 & 4 \\
\hline \multicolumn{6}{|c|}{ Explanatory variables } \\
\hline Int_RD(t-1) & 1180 & 4.90 & 12.333 & 0 & 167.310 \\
\hline Ext_RD(t-1) & 1180 & 1.96 & 6.896 & 0 & 91.767 \\
\hline Size & 1180 & 2.943 & 0.688 & 1 & 4 \\
\hline Market & 1180 & 3.624 & 0.736 & 1 & 4 \\
\hline $\mathrm{Gp}$ & 1180 & 0.887 & 0.316 & 0 & 1 \\
\hline Dumsect & 1180 & 2.761 & 1.025 & 1 & 4 \\
\hline
\end{tabular}


Table IV. Descriptive statistics for technological and organizational innovations (\%)

\begin{tabular}{|c|c|c|c|c|c|}
\hline & Values & Only_Prod(t) & Only_Proc(t) & Single(t) & Complex $(t)$ \\
\hline \multirow[t]{5}{*}{ ConOrg(t-2,t-1) } & 0 & 10.43 & 18.33 & 11.56 & 2.11 \\
\hline & 1 & 11.63 & 12.50 & 11.78 & 5.26 \\
\hline & 2 & 21.52 & 23.33 & 21.74 & 21.05 \\
\hline & 3 & 56.42 & 45.83 & 54.92 & 71.58 \\
\hline & & 100 & 100 & 100 & 100 \\
\hline \multirow[t]{5}{*}{ ConOrg(t-1,t) } & 0 & 10.03 & 15.00 & 10.76 & 6.32 \\
\hline & 1 & 21.52 & 26.67 & 22.08 & 5.26 \\
\hline & 2 & 12.03 & 15.83 & 12.59 & 1.05 \\
\hline & 3 & 56.42 & 42.50 & 54.58 & 87.37 \\
\hline & & 100 & 100 & 100 & 100 \\
\hline \multirow[t]{6}{*}{ IntOrg(t-1) } & 0 & 30.11 & 32.56 & 31.80 & 9.00 \\
\hline & 1 & 19.56 & 18.44 & 17.28 & 12.10 \\
\hline & 2 & 20.83 & 22.64 & 22.10 & 20.34 \\
\hline & 3 & 18.60 & 14.00 & 16.12 & 23.06 \\
\hline & 4 & 11.00 & 12.36 & 13.70 & 34.50 \\
\hline & & 100 & 100 & 100 & 100 \\
\hline \multirow[t]{5}{*}{ IntOrg(t) } & 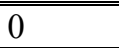 & 33.56 & 42.50 & 34.67 & 6.32 \\
\hline & 1 & 17.11 & 18.33 & 17.16 & 11.58 \\
\hline & 2 & 27.67 & 27.50 & 27.92 & 32.63 \\
\hline & 3 & 21.66 & 11.67 & 20.25 & 49.47 \\
\hline & & 100 & 100 & 100 & 100 \\
\hline Observations & & 748 & 120 & 874 & 95 \\
\hline
\end{tabular}


Table V. Dynamic RE Probit estimations (Model 1)

\begin{tabular}{|c|c|c|c|c|}
\hline & Only_Prod & Only_Proc & Single & Complex \\
\hline \multicolumn{5}{|c|}{ Lagged Innovation } \\
\hline \multirow[t]{2}{*}{ Only_prod(t-1) } & 0.230 & & & \\
\hline & $(0.177)$ & & & \\
\hline \multirow[t]{2}{*}{ Only_proc(t-1) } & & 0.143 & & \\
\hline & & $(0.220)$ & & \\
\hline \multirow{2}{*}{ Single(t-1) } & & & $0.421 * *$ & \\
\hline & & & $(0.198)$ & \\
\hline \multirow[t]{2}{*}{ Complex(t-1) } & & & & $0.507 * *$ \\
\hline & & & & $(0.221)$ \\
\hline \multicolumn{5}{|c|}{ Organizational Innovation } \\
\hline \multirow[t]{2}{*}{ ConOrg(t-1,t) } & 0.0412 & -0.0193 & $0.0521 *$ & $0.116 * * *$ \\
\hline & $(0.030)$ & $(0.035)$ & $(0.031)$ & $(0.031)$ \\
\hline \multicolumn{5}{|c|}{ Explanatory variables } \\
\hline \multirow[t]{2}{*}{ Int_RD(t-1) } & $0.005 *$ & 0.009 & $0.146 * * *$ & $-7.47 \mathrm{e}-05$ \\
\hline & $(0.003)$ & $(0.005)$ & $(0.019)$ & $(0.002)$ \\
\hline \multirow[t]{2}{*}{ Ext_RD(t-1) } & $0.022 * * *$ & -0.008 & $0.0418 * * *$ & -0.002 \\
\hline & $(0.007)$ & $(0.005)$ & $(0.013)$ & $(0.005)$ \\
\hline \multirow[t]{2}{*}{ Size } & -0.401 & 0.593 & 0.009 & 0.142 \\
\hline & $(0.297)$ & $(0.363)$ & $(0.297)$ & $(0.358)$ \\
\hline \multirow[t]{2}{*}{ Market } & $0.224 * *$ & 0.169 & $0.219 * *$ & 0.216 \\
\hline & $(0.106)$ & $(0.129)$ & $(0.102)$ & $(0.142)$ \\
\hline \multirow[t]{2}{*}{ Gp } & 0.141 & 0.348 & 0.256 & 0.315 \\
\hline & $(0.282)$ & $(0.336)$ & $(0.271)$ & $(0.344)$ \\
\hline \multirow[t]{2}{*}{ Dumsect } & -0.168 & 0.219 & -0.101 & -0.140 \\
\hline & $(0.209)$ & $(0.273)$ & $(0.212)$ & $(0.263)$ \\
\hline \multicolumn{5}{|c|}{ Individual heterogeneity } \\
\hline \multirow[t]{2}{*}{ Only_prod $(0)$} & $1.225 * * *$ & & & \\
\hline & $(0.233)$ & & & \\
\hline \multirow[t]{2}{*}{ Only_proc(0) } & & $0.834 * * *$ & & \\
\hline & & $(0.240)$ & & \\
\hline \multirow[t]{2}{*}{ Single $(0)$} & & & $0.589 * * *$ & \\
\hline & & & $(0.219)$ & \\
\hline \multirow[t]{2}{*}{ Complex $(0)$} & & & & $0.419 * *$ \\
\hline & & & & $(0.209)$ \\
\hline \multirow[t]{2}{*}{ Gpmean } & 0.248 & -0.163 & 0.063 & -0.370 \\
\hline & $(0.320)$ & $(0.367)$ & $(0.293)$ & $(0.371)$ \\
\hline \multirow[t]{2}{*}{ Dumsectmean } & -0.013 & -0.165 & 0.012 & 0.030 \\
\hline & $(0.214)$ & $(0.277)$ & $(0.217)$ & $(0.267)$ \\
\hline \multirow[t]{2}{*}{ Sizemean } & $0.798 * *$ & $-0.759 * *$ & 0.253 & 0.139 \\
\hline & $(0.313)$ & $(0.374)$ & $(0.306)$ & $(0.368)$ \\
\hline Marketmean & 0.0910 & -0.235 & -0.042 & -0.017 \\
\hline & $(0.127)$ & $(0.145)$ & $(0.116)$ & $(0.158)$ \\
\hline Intercept & $-2.581 * * *$ & $-1.370 * * *$ & $-1.721 * * *$ & $-3.049 * * *$ \\
\hline & $(0.389)$ & $(0.369)$ & $(0.296)$ & $(0.493)$ \\
\hline 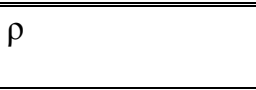 & $\begin{array}{l}0.436 \\
(0.088)\end{array}$ & $\begin{array}{l}0.346 \\
(0.117)\end{array}$ & $\begin{array}{l}0.160 \\
(0.150)\end{array}$ & $\begin{array}{l}0.045 \\
(0.164)\end{array}$ \\
\hline$-2 \ln L$ & 1114.85 & 697.47 & 912.34 & 546.07 \\
\hline $\begin{array}{l}\text { Percent correctly } \\
\text { predicted }\end{array}$ & 82.5 & 71.9 & 87.9 & 76.6 \\
\hline Observations & 2360 & 2360 & 2360 & 2360 \\
\hline
\end{tabular}

Notes: $* * *$, and $* * *$ denote significance at the $10 \%, 5 \%$, and $1 \%$ levels, respectively. Standard errors in parentheses. Random effects estimates are computed by adaptive Gausse-Hermite quadrature. 
Table VI. Dynamic RE Probit estimations (Model 2)

\begin{tabular}{|c|c|c|c|c|}
\hline & Only_Prod & Only_Proc & Single & Complex \\
\hline \multicolumn{5}{|l|}{ Lagged Innovation } \\
\hline \multirow[t]{2}{*}{ Only_Prod(t-1) } & 0.184 & & & \\
\hline & $(0.179)$ & & & \\
\hline \multirow[t]{2}{*}{ Only_Proc(t-1) } & & 0.151 & & \\
\hline & & $(0.222)$ & & \\
\hline \multirow[t]{2}{*}{ Single(t-1) } & & & $0.352 *$ & \\
\hline & & & $(0.200)$ & \\
\hline \multirow[t]{2}{*}{ Complex(t-1) } & & & & $0.381 *$ \\
\hline & & & & $(0.230)$ \\
\hline \multicolumn{5}{|l|}{ Organizational Innovation } \\
\hline \multirow[t]{2}{*}{ ConOrg(t-2,t-1) } & -0.019 & 0.005 & 0.008 & $0.063 *$ \\
\hline & $(0.029)$ & $(0.034)$ & $(0.031)$ & $(0.033)$ \\
\hline$\rho$ & $\begin{array}{l}0.466 \\
(0.086)\end{array}$ & $\begin{array}{l}0.341 \\
(0.119)\end{array}$ & $\begin{array}{l}0.214 \\
(0.145)\end{array}$ & $\begin{array}{l}0.143 \\
(0.104)\end{array}$ \\
\hline$-2 \ln \mathrm{L}$ & 1115.55 & 697.60 & 918.06 & 576.45 \\
\hline Percent correctly predicted & 82.0 & 71.0 & 86.3 & 78.4 \\
\hline Observations & 2360 & 2360 & 2360 & 2360 \\
\hline
\end{tabular}

Notes: *,**, and *** denote significance at the $10 \%, 5 \%$, and $1 \%$ levels, respectively. Standard errors in parentheses.

Table VII. Dynamic RE Probit estimations (Model 3)

\begin{tabular}{|c|c|c|c|c|}
\hline & Only_Prod & Only_Proc & Single & Complex \\
\hline \multicolumn{5}{|l|}{ Lagged Innovation } \\
\hline \multirow[t]{2}{*}{ Only_Prod(t-1) } & $0.326^{*}$ & & & \\
\hline & $(0.173)$ & & & \\
\hline \multirow{2}{*}{ Only_Proc(t-1) } & & 0.151 & & \\
\hline & & $(0.220)$ & & \\
\hline \multirow[t]{2}{*}{ Single(t-1) } & & & $0.559 * * *$ & \\
\hline & & & $(0.096)$ & \\
\hline \multirow{2}{*}{ Complex(t-1) } & & & & $0.311^{*}$ \\
\hline & & & & $(0.187)$ \\
\hline \multicolumn{5}{|l|}{ Organizational Innovation } \\
\hline \multirow[t]{2}{*}{$\operatorname{IntOrg}(\mathrm{t})$} & $0.295 * * *$ & 0.0214 & $0.309 * * *$ & $0.411 * * *$ \\
\hline & $(0.035)$ & $(0.037)$ & $(0.030)$ & $(0.045)$ \\
\hline 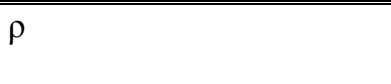 & $\begin{array}{l}0.372 \\
(0.096)\end{array}$ & $\begin{array}{l}0.343 \\
(0.118)\end{array}$ & $\begin{array}{l}0.001 \\
(0.003)\end{array}$ & $\begin{array}{l}0.073 \\
(0.130)\end{array}$ \\
\hline$-2 \ln L$ & 1072.03 & 697.00 & 864.65 & 510.34 \\
\hline Percent correctly predicted & 84.4 & 71.6 & 89.0 & 84.3 \\
\hline Observations & 2360 & 2360 & 2360 & 2360 \\
\hline
\end{tabular}

Notes: $*, * *$, and $* * *$ denote significance at the $10 \%, 5 \%$, and $1 \%$ levels, respectively. Standard errors in parentheses. 
Table VIII. Dynamic RE Probit estimations (Model 4)

\begin{tabular}{|c|c|c|c|c|}
\hline & Only_Prod & Only_Proc & Single & Complex \\
\hline \multicolumn{5}{|l|}{ Lagged Innovation } \\
\hline \multirow[t]{2}{*}{ Only_prod(t-1) } & 0.211 & & & \\
\hline & $(0.176)$ & & & \\
\hline \multirow[t]{2}{*}{ Only_proc(t-1) } & & 0.150 & & \\
\hline & & $(0.221)$ & & \\
\hline \multirow[t]{2}{*}{ Prod_ou proc(t-1) } & & & $0.352 *$ & \\
\hline & & & $(0.197)$ & \\
\hline \multirow[t]{2}{*}{ Prod_et_proc(t-1) } & & & & 0.280 \\
\hline & & & & $(0.211)$ \\
\hline \multicolumn{5}{|l|}{ Organizational Innovation } \\
\hline \multirow[t]{2}{*}{$\operatorname{IntOrg}(\mathrm{t}-1)$} & $0.080 * *$ & -0.013 & $0.101 * * *$ & $0.159 * * *$ \\
\hline & $(0.033)$ & $(0.038)$ & $(0.033)$ & $(0.035)$ \\
\hline$\rho$ & $\begin{array}{l}0.426 \\
(0.089)\end{array}$ & $\begin{array}{l}0.342 \\
(0.118)\end{array}$ & $\begin{array}{l}0.161 \\
(0.147)\end{array}$ & $\begin{array}{l}0.106 \\
(0.144)\end{array}$ \\
\hline$-2 \ln \mathrm{L}$ & 1112.45 & 697.55 & 914.36 & 567.98 \\
\hline Percent correctly predicted & 82.2 & 71.9 & 87.9 & 77.8 \\
\hline Observations & 2360 & 2360 & 2360 & 2360 \\
\hline
\end{tabular}

Notes: $*, * *$, and $* * *$ denote significance at the $10 \%, 5 \%$, and $1 \%$ levels, respectively. Standard errors in parentheses. 


\section{References}

Antonelli, C., Crespi, F. and G. Scellato. 2012. Inside innovation persistence: New evidence from Italian micro-data. Structural Change and Economic Dynamics forthcoming.

Armbruster, H., Bikfalvib, A., Kinkela, S. and Lay, G. 2008. Organizational innovation: The challenge of measuring non-technical innovation in large-scale surveys. Technovation 28: 644-657.

Baldridge, J.V and Burnham R.A. 1975. Organizational Innovation: Individual, Organizational, and Environmental Impacts. Administrative Science Quarterly 20:165176.

Battisti, G.; Stoneman, P. 2010. How innovative are UK firms? Evidence from the CIS4 on synergies between technological and organizational innovations. British Journal of Management 34 (1): 187-206.

Bharadwaj, S. and Menon, A. 2000. Making innovation happen in organizations: Individual creativity mechanisms, organizational creativity mechanisms or both. Journal of Product Innovation Management 17 (6): 424-434.

Cohen M. D. and Levinthal D. A. 1990. Absorptive capacity: A new perspective on learning innovation. Administrative Science Quarterly 35 (1): 128-152.

Cohen W. M. 1995. Empirical Studies of Innovative Activity. Chapter 6 of Handbook of the Economics of Innovation and Technological Change. Oxford: Blackwell.

Colombelli, A., Haned, N. and Le Bas, C. 2010. On firm growth and innovation. Some new empirical perspectives using French CIS (1992-2004). ICER working paper.

Cordelier C. 2009. Innovations et performances des sociétés des services et de l'industrie manufacturière, comparaisons. Working paper E 2009/06, INSEE, France.

Crossan, M. and Apaydin, M. 2010. A multi-dimensional framework of organizational innovation. Journal of Management Studies 47 (6): 1154-1191.

Daft, R.L. 1978. A dual-core model of organizational innovation. Academy of Management Review (21): 193-210.

Damanpour, F. 1991. Organizational innovation: a meta-analysis of effects of determinants and moderators. Academy of Management Journal 34 (3): 550-90.

Damanpour, F. 1992. Organizational size and innovation. Organization Studies 13 (3): 375402.

Damanpour, F., and Aravind, D. 2006. Product and process innovations: a review of organizational and environmental determinants. In Innovation, Science, and Institutional Change, Ed. J. Hage and M. Meeus. Oxford: Oxford University Press.

Damanpour, F. and Evan, W.M. 1984. Organizational innovation and performance: the problem of organizational lag. Administrative Science Quarterly (29): 392-402.

Dougherty, D. 1992. A practice-centered model of organizational renewal through product innovation. Strategic Management Journal (23): 77-92.

Duguet E. and Monjon S. 2002. Les fondements microéconomiques de la persistance de l'innovation: Une analyse économétrique. Revue Économique 53 (3) : 625-636. 
Evangelista, R. and Vezzani, A. 2010. The economic impact of technological and organizational innovations. A firm-level analysis. Research Policy (39): 1253-1263.

Geroski P. A., van Reenen J. and Walters C. F.1997. How persistently do firms innovate?. Research Policy 26 (1): 33-48.

Greenan, N., Guellec, D., Broussaudier, G. and Miotti, L. 1993. Innovation organisationnelle, dynamisme technologique et performance des entreprises. Working paper G9304/ April, INSEE, France.

Gumusluoğlu, L. and Ilsev, A. 2009. Transformational leadership and organizational innovation: the roles of internal and external support for innovation. Journal of Product Innovation Management 26: 264-277.

Gunday, G., Ulusoy, G., Kilic, K., and Alpkan, L. 2011. Effects of innovation types on firm performance. International Journal of Production Economics 133(2): 662-676.

Heckman, J.J. 1981. The incidental parameters problem and the problem of initial conditions in estimating a discrete time discrete data stochastic process. In The structural analysis of discrete. Ed. C. Manski and D. McFadden. Boston: MIT Press.

Henderson, R. and Clark, K. 1990. Architectural innovation: the reconfiguration of existing product technologies and the failure of established firms. Administrative Science Quarterly 35: 9-30.

Kimberly, J.R. and Evanisko, M.J. 1981. Organizational Innovation: the influence of individual, organizational, and contextual factors on hospital adoption of technological and administrative innovations. Academy of Management Journal 24 (4): 689-713.

Lam, A. 2005. Organizational innovation. In The Oxford Handbook of Innovation, ed. Jan Fagerberg J., Mowery D.C., Nelson R.R. Oxford: Oxford University Press.

Latham W., and Le Bas, C. 2006. The Economics of Persistent Innovation, Berlin and New York: Springer.

Le Bas, C., Poussing, N. 2012. Are complex innovators more persistent than single innovators? An empirical analysis of innovation persistence drivers. Working Paper 1201, GATE, Lyon Saint-Etienne, France.

Lokshin, B., Van Gils, A. and Bauer, E. 2008a. Crafting firm competencies to improve innovative performance. Working Paper, UNU-MERIT, available at: http://www.merit.unu.edu/publications/wppdf/2008/wp2008-009.pdf (accessed 12 November 2011).

Lokshin B., Belderbos R. and Carree M. 2008b. The productivity effects of internal and external R\&D: evidence from a dynamic panel data model. Oxford Bulletin of Economics and Statistics 70 (3): 399-413.

Love, J. H. and Roper, S. 2001. Location and network effects on innovation success: evidence for UK, German and Irish manufacturing plants. Research Policy 30 (4): 643-661.

Mairesse J. and Mohnen P. 2010. Using innovations surveys for econometric analysis. NBER working paper series 15857. http://www.nber.org/papers/w15857.

Mothe C. and Nguyen U. 2010. The link between non technological innovations and technological innovation. European Journal of Innovation Management 13 (3): 313-332. 
Mothe C. and Nguyen U. 2012. Non-technological and technological innovations: Do services differ from manufacturing? An empirical analysis of Luxembourg firms, International Journal of Technology Management, forthcoming.

Nelson, R. R and Winter, S. G. 1982. An Evolutionary Theory of Economic Change. The Belknap Press of Harvard University Press: Cambridge.

OECD. 2005. Oslo Manual. $3^{\text {rd }}$ edition.

Pavitt K. 2005. Innovation Processes. In Jan Fagerberg J., . Mowery D.C., Nelson R.R., Eds, The Oxford Handbook of Innovation. Oxford Handbooks in Business and Management. pp 86-114.

Penrose, E. T. 1959. The Theory of the Growth of the Firm. New York: John Wiley.

Peters, B. 2008. Persistence Effects of Innovation Activities. In Peters, B, Ed, Innovation and firm performance. Physica Verlag, Zew Economic Studies 38, pp. 151-199.

Phillips, R. 1997. Innovation and firm performance in Australian manufacturing, industry commission, Staff Research Paper, Canberra.

Polder M, Leeuwen GV, Mohnen P, Raymond W (2010). Product, process and organizational innovation: drivers, complementarity and productivity effects, United Nations University Maastricht Economic and social Research and training centre on Innovation and Technology, Maastricht, The Netherlands.

Raymond, W., Mohnen, P., Palm, F.C. and Schim Van Der Loeff, S. 2010. Persistence of innovation in Dutch manufacturing: Is it spurious? Review of Economics and Statistics 92 (3): 495-504.

Schmidt, T. and Rammer, C. 2007. Non-technological and technological innovation: strange bedfellows?. Working Paper 07-052, ZEW, available at: ftp://ftp.zew.de/pub/zewdocs/dp/dp07052.pdf (accessed 12 November 2011).

Staropoli, K. 1998. Cooperation in R\&D through a network, an organizational gamble? An empirical analysis of Rhône Poulenc Rorer-Gencell. Technology Analysis and Strategic Management 10 (4): 511-527.

Tatikonda, M.V. and Montoya-Weiss, M.M. 2001. Integrating operations and marketing perspectives of product innovation: the influence of organizational process factors and capabilities on development performance. Management Science 47 (1): 151-172.

Teece, D. J. 1988. Technological change and the nature of the firm. In Technical Change and Economic Theory. Ed. G. Dosi, C. Freeman, R. Nelson, G. Silverberg and L. Soete. New York: Pinter Publishers.

Wernerfelt, B. 1984. A resource-based view of the firm. Strategic Management Journal 5 (2): $171-180$.

Wooldridge, J. M. 2005. Simple solutions to the initial conditions problem in dynamic nonlinear panel data models with unobserved heterogeneity. Journal of Applied Econometrics 20 (1): 39-54. 